\title{
ELECTROLYTIC DISSOLVER FOR POWER FUELS
}

\author{
V.P. Caracciolo \\ A. A. Kishbaugh
}

SRL

RECORD COP

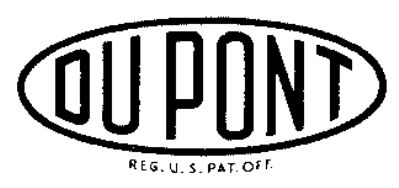

Savannah River Laboratory

Aiken, South Carolina 


\section{LEG A L NOTICE}

This report was prepared as an account of Government sponsored work. Neither the United States, nor the Commission, nor any person acting on behalf of the Commission:

A. Makes any warranty or representation, expressed or implied, with respect to the accuracy, completeness, or usefulness of the information contained in this report, or that the use of any information, apparatus, method, or process disclosed in this report may not infringe privately owned rights; or

B. Assumes any liabillties with respect to the use of, or for damages resulting from the use of any information, apparatus, method, or process disclosed in this report.

As used in the above, "person acting on behalf of the Commission" includes any employee or contractor of the Commission, or employee of such contractor, to the extent that such employee or contractor of the Commission, or employee of such contractor prepares, disseminates, or provides access to, any information pursuant to his employment or contract with the Commtssion, or his employment with such contractor.

Printed in USA. Price $\$ 2.00$

Avallable from the Clearinghouse for Federal Scientific and Technical Information, National Bureau of Standards,

U. S. Department of Commerce, Springfield, Virginia 
Engineering and Equipment

(TID-4500, 34th Ed.)

\title{
ELECTROLYTIC DISSOLVER FOR POWER FUELS
}

\author{
by \\ Vincent P. Caracciolo \\ Albert A. Kishbaugh
}

Approved by

D. S. Webster, Research Manager

Separations Engineering Division

October 1964

E. I. DU PONT DE NEMOURS \& COMPANY

SAVANNAH RIVER LABORATORY

AIKEN, SOUTH CAROLINA

CONTRACT AT(07.2)-1 WITH THE

UNITED STATES ATOMIC ENERGY COMMISSION 


\section{ABSTRACT}

A 5000-ampere electrolytic dissolver was built and successfully operated with unirradiated fuel assemblies. Practical rates of dissolution were obtained with fuel assemblies of $\mathrm{UO}_{2}$ clad in stainless steel or Z1rcaloy; $\mathrm{UO}_{2}$ - stainless steel cermet plates clad in stainless steel; and stainless-steel-clad, sodium-bonded uranium rods. 


\section{CONTENTS}

Page

List of Tables and Figures 4

Introduction 5

Summary 6

Discussion $\quad 7$

The Liquid Contact Principle 7

Design of the Electrolytic Dissolver 8

Electrode Assembly 8

Insulating Basket 11

Limiting Current Density $\quad 14$

Platinum Corrosion $\quad 14$

Corrosion by Stray Currents 16

Operation of the Dissolver 19

Typical Operating Results 20

Stainless-Steel-Clad Fuels 20

Zirca.loy-Clad Fuels 22

$\mathrm{UO}_{2}$ - Stainless Steel Cermet Fuels 25

Sodium-Bonded Fuels 26

Aluminum Fuels 30

Estimation of Dissolver Capacity 30

Bibliography 31 


\section{LIST OF TABLES AND FIGURES}

$\underline{\text { Table }}$

Page

I Reaction Potential in N1tric Acid and Electrochemical Equivalent $\quad 7$

II Breakdown Potential for Valve Metals 8

III Resistivity 10

IV Effect of Nitric Acid on NEMA Grade G-7 Plastic II

V Tank Corrosion by Stray Currents 19

Figure

1 Assembly View of Iiquid Contact Electrolytic Dissolver 9

2 Design of Electrodes for Liquid Contact Dissolver 10

3 Silicone-Glass Basket 12

4 Columblum Basket 13

5 Maximum Current Density at Platinum Anode 15

6 Corrosion of Platinum Electrodes 16

7 Tank Corrosion with No Cathodic Shield 17

8 Cathodic Shield 18

9 Mock Assembly of Stainless Steel Fuel Elements 21

10 Operating Characteristics - Stainless steel Charge 23

11 Zircaloy-4 Mock Power Fuel Assembly 23

12 Zircaloy-4 Mock Power Fuel - Heel 24

13 Operating Characteristics - Zircaloy-Clad-UO

14 Stainless Steel Cermet Assembly 26

15 Operating Characterist1cs - Stainless Steel Cermet Fuels 27

16 Simulated Hallam Sodium-Bonded Fuels 28

17 Solution Composition - Simulated Hallam SodiumBonded Fuels 


\section{ELECTROLYTIC DISSOLVER FOR POWER FUELS}

\section{INTRODUCTION}

Most of the power reactor fuels in use today or planned for use in the near future include stainless steel or zirconium components. A large number contain $\mathrm{UO}_{2}$ pellets swaged into stainless steel or Zircaloy tubes, some are cermet mixtures of $\mathrm{UO}_{2}$ and stainless steel powder, some are U-Zr alloys, and others are uranium alloys bonded to stainless steel tubes with sodium; all resist attack by nitric acid, which is the most widely accepted dissolvent for recovery of uranium and plutonium from fuels. Electrolytic dissolution of all these fuels in nitric acid has been recognized as a possibility that has the virtue of allowing solvent extraction by conventional means in conventional stainless steel equipment. The normally resistant metals and alloys will dissolve or disintegrate anodically in nitric acid at practical rates. In 1951, E. C, Pitzer at Knolls Atomic Power Laboratory showed that it was feasible to anodically dissolve stainless-steel-clad fuels in nitric acid(1). More recent work shows that the technique is applicable to many other alloys: small-scale studies have been made by Martin and Waterman $(2)$, Henry ${ }^{(3)}$, Clark, et al. (4), Slansky, et al. $(5,6)$, and Rhode and Bowman ( 7 ). References 5, 6, and 7 are from the Idaho Chemlcal Processing Plant, where much work has been done on electrolytic dissolution.

Work at the Savannah River Laboratory by Clark, et al. (4), showed that useful rates of dissolution and low losses of uranium or plutonium could be expected for all fuels, except for the $\mathrm{Zr}-\mathrm{U}$ alloys; in the latter case, the $\mathrm{ZrO}_{2}$ sludge that formed during anodic attack carried uranium, causing a nonleachable, 50\% loss of uranium. This work also showed that tantalum and columbium, candidate anode materials, retained their "electrolytic valve" properties after exposure to a radiation dose of $10^{9} \mathrm{rad}$.

A 5000-ampere dissolver was installed at the SRI Semiworks in early 1961. The design was based on the "metal contact" concept in which the fuel assemblies to be dissolved were placed in an anodic $\mathrm{Cb}$ basket surrounded by $\mathrm{a}$. $\mathrm{Cb}$ cathode. Since the "electrolytic valve" action of $\mathrm{Cb}$ prevented current flow directly from the anode, current passed to the assemblies by metal contact, then to the cathode electrolytically via holes in the basket. Mock assemblies of stainless steel and Zircaloy were dissolved, but the rate of dissolution was erratic and limited because of the build-up of an oxide layer produced by arcing between the anodic basket and the assemblies $(8-10)$. The limited capacity and inherent instability of "metal contact" did not justify further work. 
In late 1961, the dissolver was converted to a "liquid contact" system in which the fuel assemblies to be dissolved are suspended between a platinum-clad columbium anode and a columbium cathode. The electrodes are arranged so that the fuel charge, which does not touch either electrode, provides the main path for passage of current between them. Under such conditions, anodic dissolution will occur on the side of the fuel charge facing the cathode. This report is a summary of the development and operational tests of this dissolver. Additional details of the work are given in previous Savannah River Laboratory reports $(11-1 B)$.

\section{SUMMARY}

A 5000-ampere electrolytic dissolver was built and successfully operated with unfrradiated fuel assemblies for over two million ampere-hours using the "liquid contact" principle. Stainless steel or Zircaloy claddings of $\mathrm{UO}_{2}$ fuel were dissolved at 0.5 and 0.25 gram per ampere-hour, respectively. Assemblies of $\mathrm{UO}_{2}$-stainless steel cermets, aluminum, and sodium-bonded uranium alloys were successfully dissolved at rates comparable to their electrochemical equivalents.

Dissolver capacity is limited by the ability to remove heat near the surface of the electrodes as the current density is increased. Factors for predicting the capacity of a dissolver were defined. 


\section{DISCUSSION}

\section{THE LIQUID CONTACT PRINCIPLE}

When an electrode is clamped to one end of a stainless steel rod and the other end is immersed in nitric acid near a cathode, the part of the rod nearest the cathode will begin to dissolve if the applied potential exceeds the reaction potential. As an alternative to an electrode clamp, the rod can be placed in a perforated basket of inert meta I $^{*}$ surrounded by a cathode; when the basket is made anodic, the rod is also made anodic by metal-to-metal contact with the basket, and dissolving begins. This technique, sometimes called "metal contact", provides a low capacity for dissolving the metals of interest because of the difficulty in maintaining good electrical contact between the rod and the basket(8-10).

A "liquid contact" system results when the rod or fuel charge is suspended in nitric acid between a platinum anode and a cathode in such a way as to allow the charge to pass most of the current. Current leaves the platinum by electrolysis of nitric acid, accompanied by the production of oxgyen and oxides of nitrogen. The current is accepted by the cathode with the production of oxides of nitrogen and a small amount of hydrogen. In order for current to flow through the metal charge, the potential difference in the electrolyte between points touching the extremes of the charge must exceed the combined anodic and cathodic reaction potentials of the charge. Typical reaction potentials for metals in nitric acid are given in Table $I$.

\section{TABLE I}

Reaction Potential in Nitric Acid and Eilectrochemical Equivalent

\begin{tabular}{|c|c|c|}
\hline Material. & $\begin{array}{l}\text { Combined Reaction } \\
\text { Potent1al, volts }\end{array}$ & $\begin{array}{c}\text { Electrochemical } \\
\text { Equivalent, } \\
\mathrm{g} / \mathrm{amp}-\mathrm{hr} \\
\end{array}$ \\
\hline Stainless steel & 1.1 & 0.59 \\
\hline Aluminum & 1.95 & 0.33 \\
\hline Zirconium & $3-4$ & 0.85 \\
\hline Urantum & - & 2.5 \\
\hline Pt $-\mathrm{Cb}$ electrodes & 2.8 & - \\
\hline
\end{tabular}

* An inert metal is one which will pass current as a cathode, but not as an anode (rectifying action), usually because of the formation of a nonconducting oxide layer in the anodic situation. The rectifying action of a suitable "valve metal" will not break down until the potential exceeds 50 to 100 volts. 


\section{DESIGN OF THE ELECTROLYTIC DISSOLVER}

The successful application of the "liquid contact" principle was demonstrated at the SRL Semiworks in the 5000ampere dissolver shown in Figure 1. The dissolver was used to develop the necessary design information to bulld larger units and to demonstrate the dissolution of various power fuels.

\section{Electrode Assembly}

The electrodes must be massive enough to give strength and high conductance to the electrode assembly, and must be constructed of materials that are not subject to electrochemical or chemical attack. Platinum, essentially the only material that is not severely attacked as an anode in nitric acid, is used as a cladding on an inert base metal to reduce costs. Columbium and tantalum are suitable inert base metals for the anode $(27)$, as long as the breakdown potential, given in Table II, is not exceeded. Titanium also forms a protective oxide film, but the breakdown potential is too low for practical use as an anode material. The cathode can be constructed of columbium, tantalum, or titanium, all of which are resistant to chemical attack in nitric acid with current flow.

\section{TABLE II}

Breakdown Potent1al for Valve Metals

\begin{tabular}{|c|c|c|}
\hline Material & $\begin{array}{c}\text { Breakdown } \\
\text { Potential }(a), \\
\text { volts } \\
\end{array}$ & $\begin{array}{l}\text { Action in a Liquid } \\
\text { Contact Celi Below } \\
\text { Breakdown Potentlal }\end{array}$ \\
\hline Titanium & $3-5$ & Can be cathode only \\
\hline Columbium & 45 & Can be cathode only \\
\hline Tantalum & 140 & Can be cathode only \\
\hline Platinum & N11 & Can be anode or cathode \\
\hline
\end{tabular}

(a) Potentla.l required to pass current of $1 \mathrm{ma} / \mathrm{cm}^{2}$ In $70 \% \mathrm{HNO}_{3}$ at $25^{\circ} \mathrm{C}$ when used as an anode. ( 17 )

Current enters and leaves the dissolving metal through the nitric acid electrolyte. Since the major resistance in the cell is due to the electrolyte (resistivities are shown in Table III), the cell should be designed with the shortest possible path through electrolyte. Therefore, the best cell (one with the lowest potential drop) is one in which the fuel 


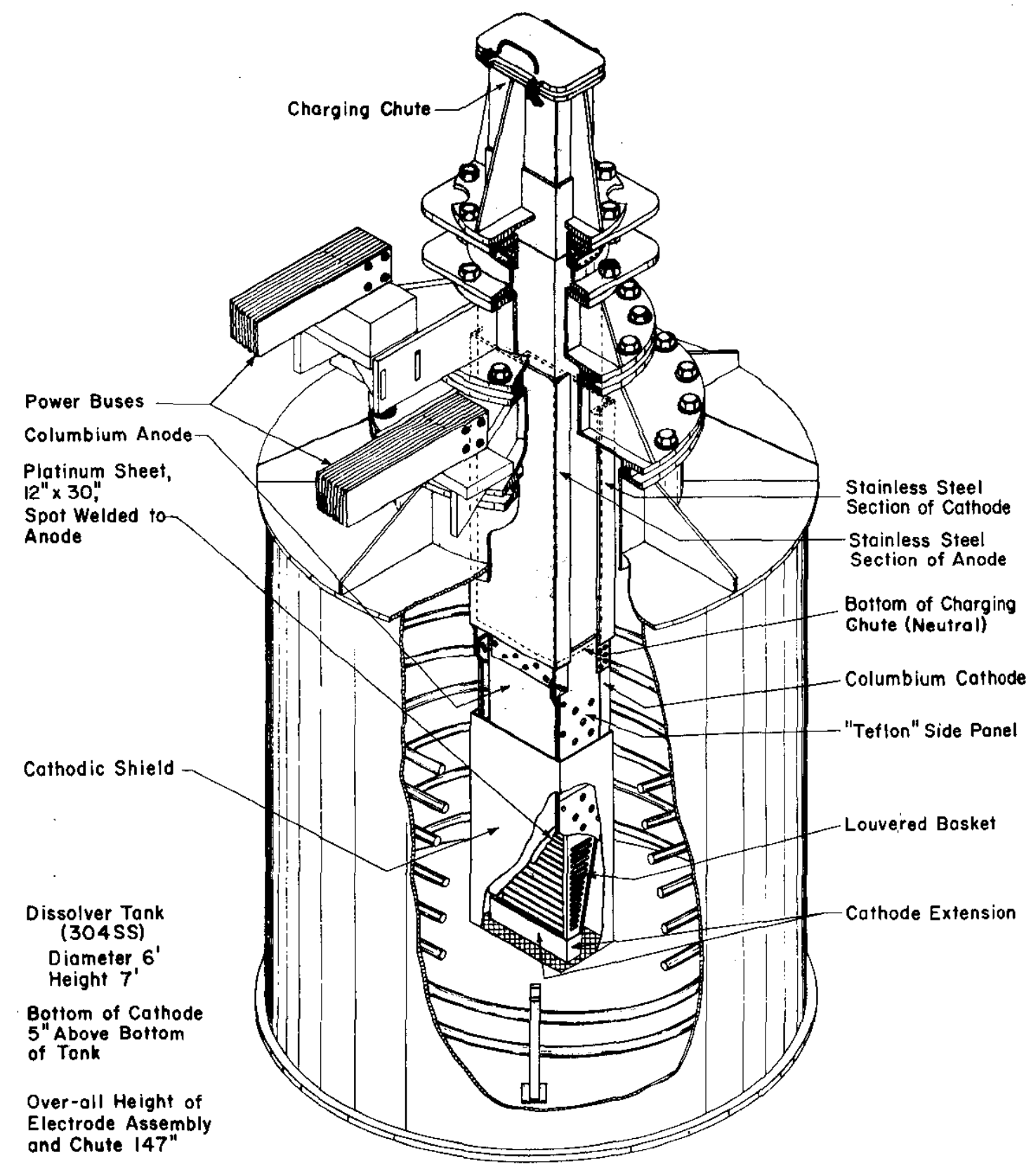

FIG. I ASSEMBLY VIEW OF LIQUID CONTACT ELECTROLYTIC DISSOLVER 
Resist1vity

Material

$5.5 \mathrm{M} \mathrm{HNO} 3$

1. $9 \mathrm{M} \mathrm{HNO}_{3}$

4. $0 \mathrm{M} \mathrm{HNO}_{3}, 10 \mathrm{~g} / \mathrm{I}$ stalnless steel

1. $9 \mathrm{M} \mathrm{HNO}_{3}, 50 \mathrm{~g} / 1$ stalnless steel

Stainless steel
Resistivity, ohm-cm

$18^{\circ} \mathrm{C} \quad 50^{\circ} \mathrm{C} \quad 95^{\circ} \mathrm{C}$

$\begin{array}{lll}1.27 & 0.91 & 0.64 \\ 2.0 & 1.43 & 1.0 \\ 1.5 & 1.07 & 0.75 \\ 3.2 & 2.3 & 1.6 \\ 6 \times 10^{-5} & - & -\end{array}$

$6 \times 10^{-5}$

assembly remains close to the electrodes at all times without touching them. Contact between the fuel assembly and the electrode is prevented by placing the charge in a perforated basket located between the electrodes and insulated from them. Since dissolution takes place near the cathode, the submerged part of the cathode and the facing part of the basket should be sloped inward toward the anode, as shown in Figure 2; the degree of slope is not critical. As a charge dissolves and moves downward, it takes the shape of the electrode cavity and always remains close to each electrode. The cathode is also extended at the bottom to a position under the anode, to ensure against a slowly dissolving tip on the charge limiting the rate of downward movement.

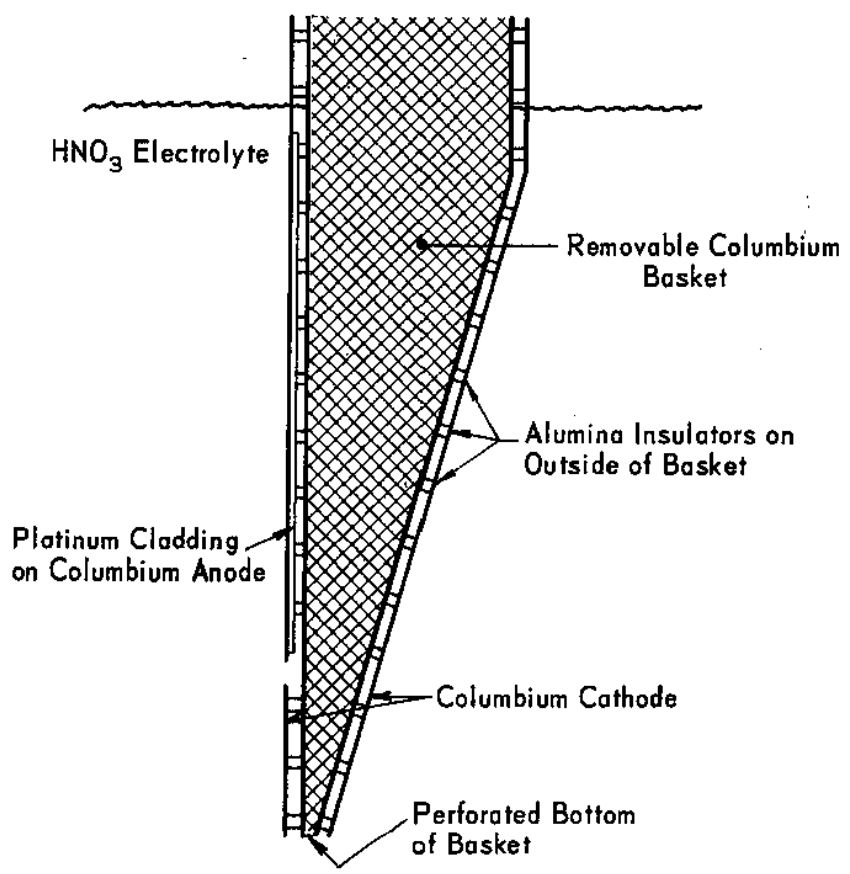

FIG. 2 DESIGN OF ELECTRODES FOR LIQUID CONTACT DISSOLVER 
The electrodes in the Semiworks dissolver are made of '1/8inch-thick columbium metal. A lo-mil sheet of platinum, 12 inches wide and 30 inches high, was spot welded to the inside of the anode. The $\mathrm{Cb}$ electrodes extend about $1-1 / 2 \mathrm{ft}$ above the normal liquid level; the upper parts of the electrodes are stainless steel which is bolted to the $\mathrm{Cb}$. The sides of the electrode compartment are "Teflon"*; in a dissolver for radioactive service, "Teflon" cannot be used, but the $\mathrm{Cb}$ anode and cathode can be extended to form an enclosure strong enough to be self-supporting.

The electrode cavity is about $7 \times 14$ inches in cross section; when immersed in electrolyte, about $1.5 \mathrm{ft}^{2}$ of $\mathrm{Pt}$ is available for current flow. The electrodes are suspended from the top of the tank, as shown in Figure 1, with the bottom of the cathode 5 inches above the bottom of the tank. A 4-scfm alr sparge, not shown in the figure, is located directly below the electrodes to provide liquid circulation through the electrode cavity.

\section{Insulating Basket}

The liquid contact cell requires that the material to be dissolved remain as close to the electrode a.s possible. This is accomplished by placing a removable basket between, and insulated from, the electrodes. Two basket designs were evaluated, one constructed of NEMA Grade G-7 plastic (laminate of silicone resin and glass fabric which was the only suitable plastic material that held up well in a radiation field to a total exposure of $5 \times 10^{9}$ rad), the other of columbium which was insulated on the outside with alumina spacers. The basket made of G-7 plastic (Figure 3) failed by weakening in nitric acid after about 100 hours of use in the electrolytic dissolver (Table IV). The failure occurred in the large louvered walls

\section{TABIE IV}

Effect of Nitric Acid on NEMA Grade G-7 Plastic

\begin{tabular}{|c|c|c|c|}
\hline Conditions & $\begin{array}{l}\text { Weight } \\
\text { Loss, } \\
\% / \mathrm{hr} \\
\end{array}$ & $\begin{array}{c}\text { Ultimate Tensile } \\
\text { Strength, } \\
\text { psi }\end{array}$ & $\begin{array}{c}\text { Izod Impact } \\
\text { no notch), } \\
\text { ft-lb } \\
\end{array}$ \\
\hline Before exposure & & 24,780 & 8.25 \\
\hline $\begin{array}{l}75 \mathrm{hr} \text { in } 5 \mathrm{M} \mathrm{HNO}_{3} \\
\text { at } 80-95^{\circ} \mathrm{C}\end{array}$ & 0.1 & 4,100 & 3.0 \\
\hline $\begin{array}{l}95 \mathrm{hr} \text { in } 6 \mathrm{M} \mathrm{HNO}_{3} \\
\text { at } 70^{\circ} \mathrm{C}\end{array}$ & 0.04 & - & - \\
\hline
\end{tabular}

* Du Pont's trademark for its fluorocarbon plastic. 


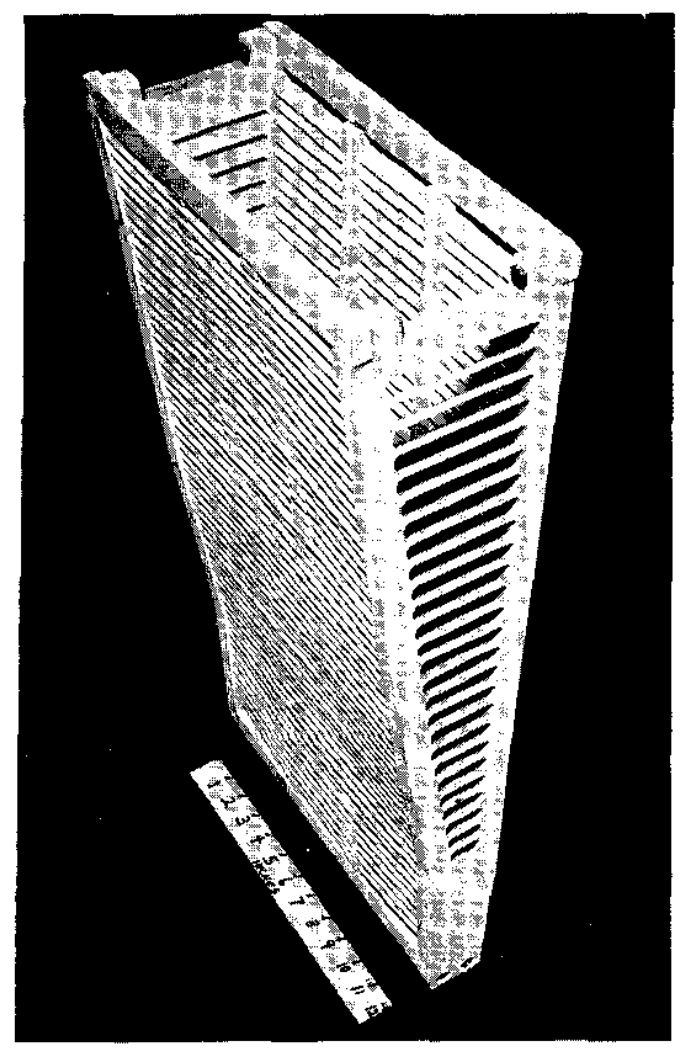

FIG. 3 SILICONE.GLASS BASKET

that faced the electrodes. The poor resistance of the plastic to continuous exposure in nitric acid prevents use in the electrolytic dissolver below the liquid level. The columbium basket proved satisfactory and was used during the demonstration runs in the 5000-ampere dissolver. An end view of the electrodes with the basket installed is shown in Figure 4. The preferred design for a dissolver is more rugged than the one shown; the louvered design of the G-7 basket, which prevents pieces of the charge from falling through the openings and touching the electrodes, should be combined with the durability of columblum and alumina. The basket should have an open area of at least $50 \%$ in the sides facing the electrodes to minimize resistance to current flow. A columbium basket has the advantages of ruggedness and long life to offset cost and the fact that it is conductive. The columbium basket can become charged anodically by "liquid contact" and then discharge through the fuel assemblies by "metal contact". Although only a small fraction of the current would flow through the basket, the contact points between basket and fuel will eventually be damaged by electrical arcing. However, with the basket submerged in electrolyte, the arcing heat is removed rapidly so that damage is limited. A $\mathrm{Cb}$ basket is expected to have a useful life of at least one year. 

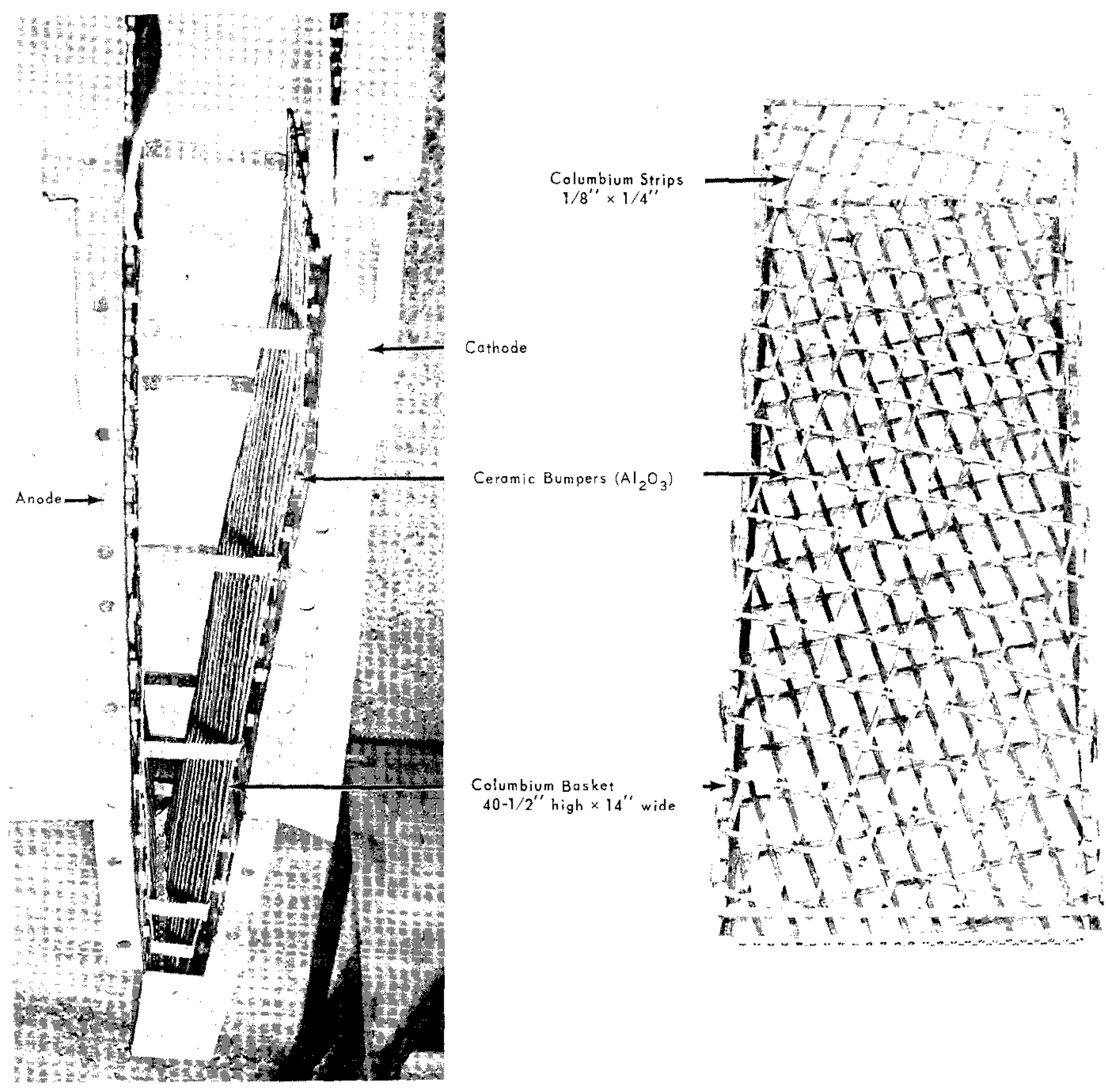

FIG. 4 COLUMBIUM BASKET 


\section{Limiting Current Density}

Essentlally a.ll of the power required to operate the cell is dissipated as heat in the nitric acid electrolyte. If the heat is not removed, the acid will boil and blanket the electrode with vapor, causing a rapid increase in resistance. The result is that a maximum current density is reached for a given electrode-fuel assembly conflguration and bulk acld temperature. The limiting current density can be increased by lowerirg the temperature of the bulk electrolyte and/or by increasing the flow of the electrolyte past the electrode.

To define the limiting current density for electrodes of a. practical size, maximum current densities were measured in the laboratory as a function of liquid temperature and electrode height for anodes of platinum, stainless steel, and aluminum and for cathodes of stainless steel and columbium(11). The limiting current density for platinum anodes was found to be 10 to $20 \%$ lower than for the other materials under the same conditions. The practical conclusion is that current density or dissolving rate is not limited by the cladding or cathode material, but only by the area of the platinum anode. The limiting current density was independent of the concentration of acid between 3 and $6 \mathrm{M}$ and, as expected, increased as the temperature of the electrolyte was lowered and as the electrolyte was agitated. Maximum current densities for platinum anodes of three stzes were measured and are shown in Figure 5 as functions of the height of the electrode and the difference between the temperature of the electrolyte and its boiling point. The electrode height is plotted as the reciprocal one-fourth root, which is the standard function used for the transfer of heat to fluids by natural convection. At a given temperature difference, the taller the electrode, the lower the maximum current density. The maximum current densities predicted in Figure 5 for the Semiworks dissolver compared favorably with the actual data obtained. The dissolver was operated successfully at current densities a.s high a.s 3500 $\operatorname{amp} / f t^{2}$.

\section{Platinum Corrosion}

Platinum is used in the electrolytic dissolver as the anode cladding because it is essentially the only material that is not severely corroded during anodic reaction in nitric acid; the cathode may be clad in platinum to prevent hydrogen embrittlement, although most of the atomic hydrogen reacts with nitric acid, liberating nitrogen tetroxide(18). Tests of the corrosion of platinum electrodes in nitric acid showed that platinum is not a completely passive electrode 


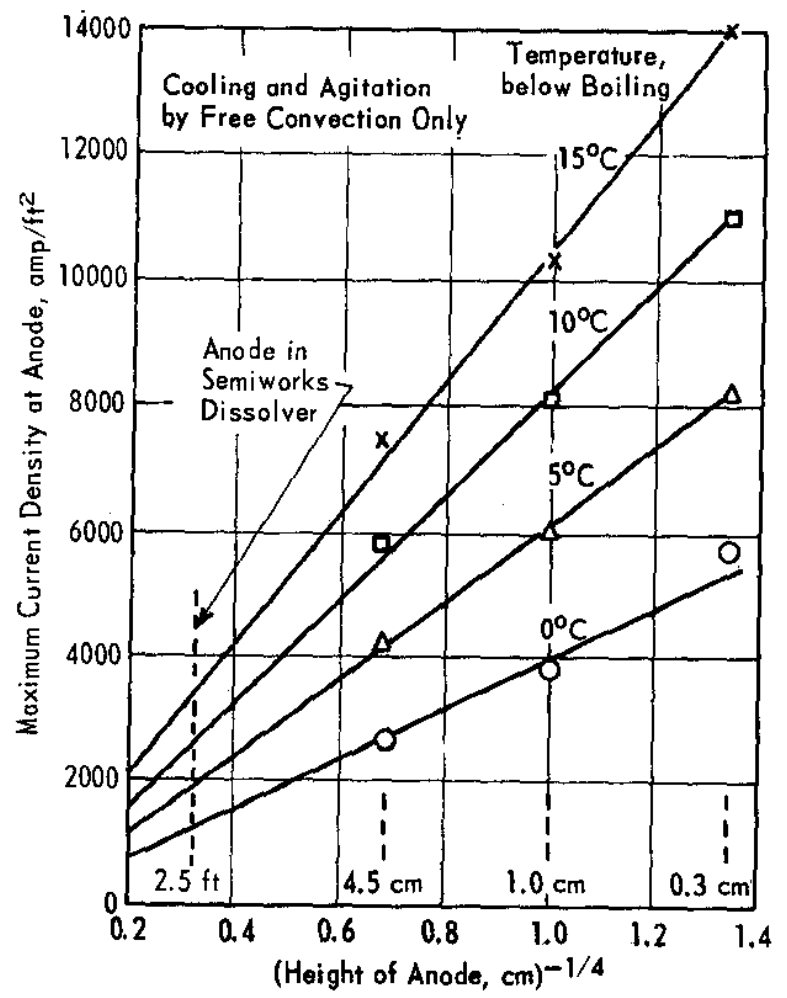

FIG. 5 MAXIMUM CURRENT DENSITY AT PLATINUM ANODE

material and that significant rates of attack can occur. However, under the operating conditions in the dissolver $\left(4-8 \mathrm{M} \mathrm{HNO}_{3}, 60^{\circ} \mathrm{C}\right)$, the rate of attack is not excessive, averaging $1.8 \mathrm{mpy}$ for the anode and $0.5 \mathrm{mpy}$ for the cathode. The effects of nitric acid concentration and temperature are summarized in Figure 6 . Since the corrosion rate of each electrode is essentially independent of current density, the corrosive action is not a typical electrolytic effect. The inverse influence of $\mathrm{HNO}_{3}$ concentration on corrosion was not expected; the rate of corrosion of the anode increases rapidly with decreasing acidity, whereas the corrosion rate of the cathode decreases with decreasing acidity, to the point at which there is an actual wejght gain of the cathode at low acid concentrations. The gain is caused by the formation of a dark gray film that presumably is platinum metal or hydride. The rate of corrosion of the anode increased rapidly with increasing temperature as shown in Figure 6 . The cathode corrosion increased slightly in $8 \mathrm{M} \mathrm{HNO}_{3}$ with increasing temperature, and the rate of weight gain at low acidities was accelerated by increased temperatures. The platinum corrosion rate was not significantly affected by the presence of dissolved stainless steel or uranium. 

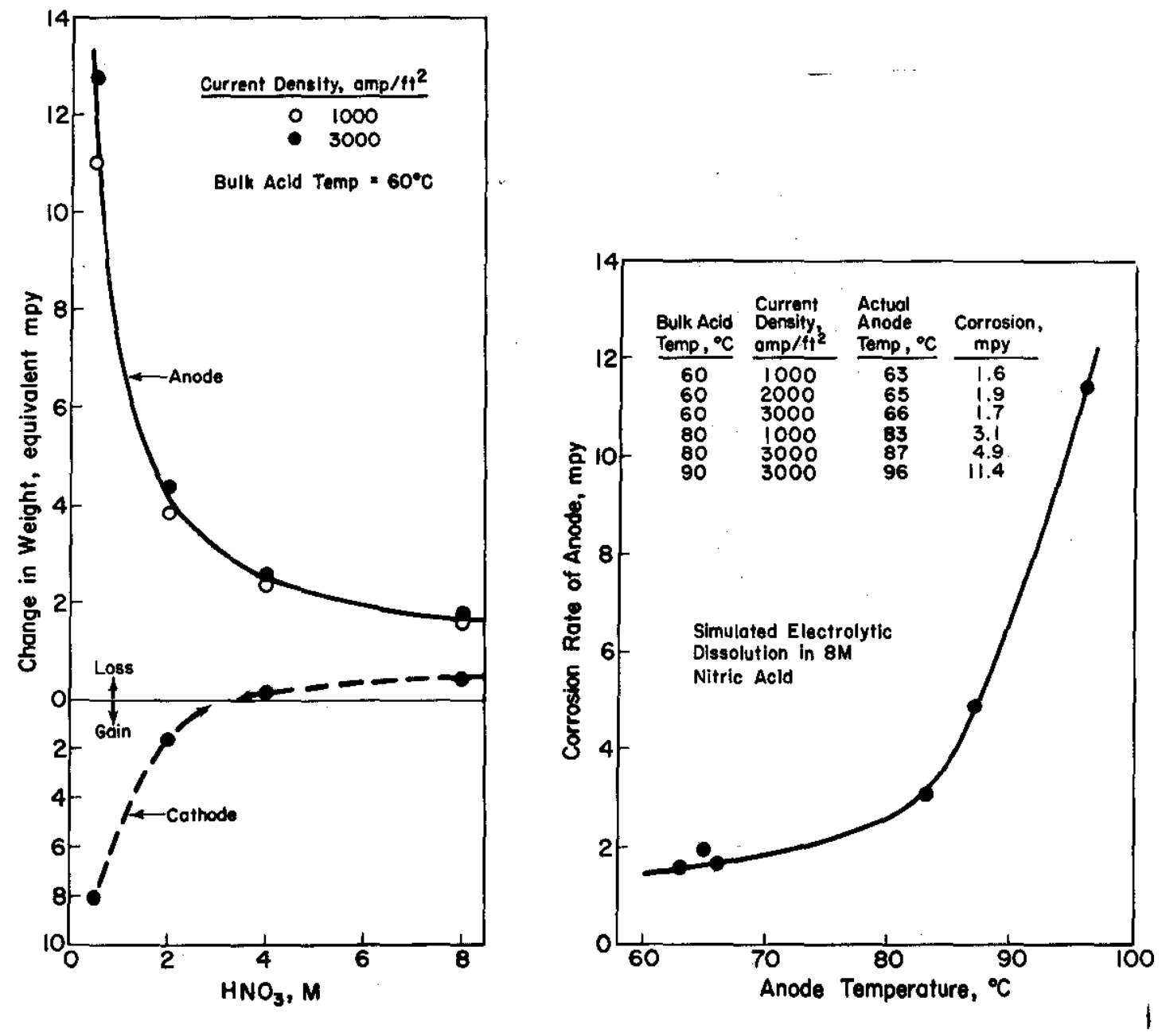

FIG. 6 CORROSION OF PLATINUM ELECTRODES

Corrosion by Stray Currents

The stainless steel tank is grounded and the electrodes are insulated from the tank. In the Semiworks dissolver the anode is as much as 25 volts above ground potential. Localized anodic corrosion of the dissolver tank was noted after long operation. The corrosion was 50-100 mpy and was limited to an area behind the cathode, particularly on the tank bottom as shown in Figure 7 . Corrosion became negligible when the anode and the bottom of the cathode were enclosed in a shield at cathode potential (Figure 8 ). The shield prevented current leakage to the tank from the Pt anode or from the dissolving metal, which is also anodic; the cathode-to-ground potentlal was -0.5 to -1.0 volt with the shield in place. 


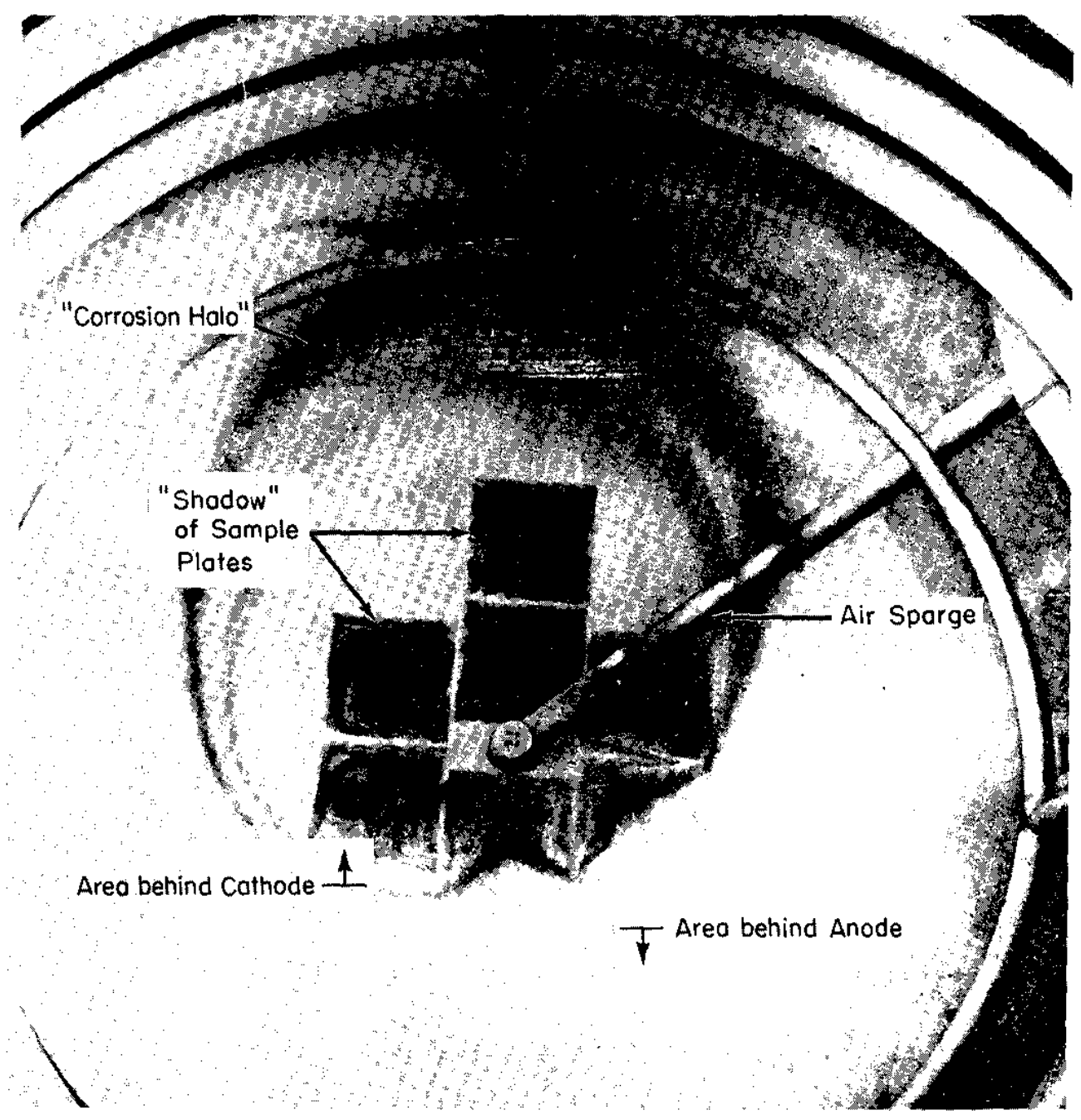

FIG. 7 TANK CORROSION WITH NO CATHODIC SHIELD 


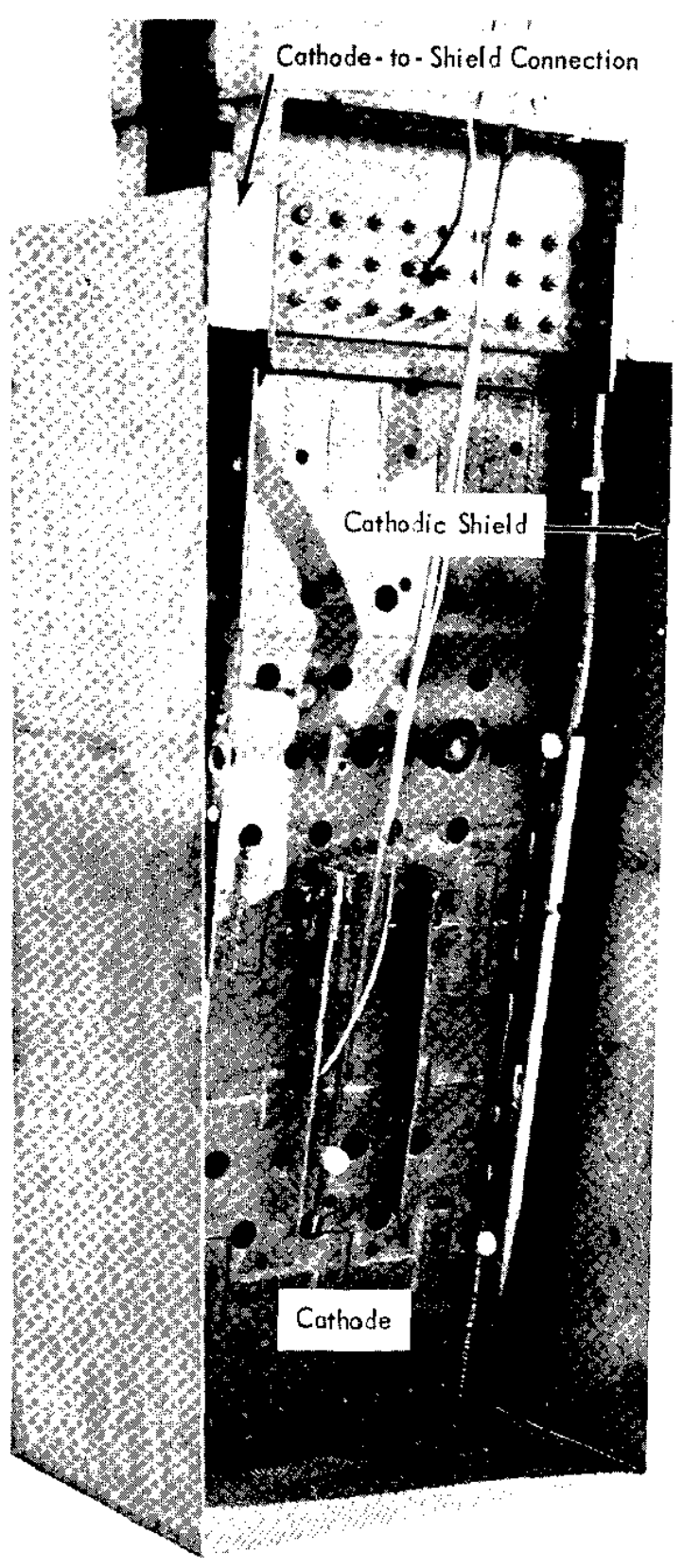

FIG. 8 CATHODIC SHIELD 
Another method of reducing tank corrosion is to make the tank cathodic by connecting the tank to the cathode. Since stainless steel corrodes as a cathode at only about $I / 10$ the anodic rate, corrosion due to stray currents should be small and probably would occur unfformly over the entire tank, particularly if the tank is distant from the electrode assembly. However, this method of protection is not as desirable as a cathodic shield because the amount of stray current is unknown and could become localized depending on the physical arrangement and the electrode-to-tank potentials. Test data are summarized in Table V.

\section{TABLE V}

Tank Corrosion by Stray Currents

\begin{tabular}{|c|c|c|c|}
\hline Conditions & $\begin{array}{l}\text { Cathode-to- }(a), \\
\text { Ground Potent1al } \\
\text { volts }\end{array}$ & $\begin{array}{c}\text { Corrosion, } \\
\text { mpy } \\
\end{array}$ & Area Attacked \\
\hline $\begin{array}{l}\text { No cathodic } \\
\text { shield }\end{array}$ & -1.5 to -2.0 & 50 to 100 & $\begin{array}{l}\text { Behind cathode in } \\
\text { large area of tank } \\
\text { bottom and colls }\end{array}$ \\
\hline $\begin{array}{l}\text { Tank connected } \\
\text { to cathode }\end{array}$ & +1.5 to +2.0 & 2 & $\begin{array}{l}\text { Appeared uniform } \\
\text { over entire tank } \\
\text { bottom }\end{array}$ \\
\hline $\begin{array}{l}\text { Full cathodic } \\
\text { shield }\end{array}$ & -0.5 to -1.0 & $<0.5$ & $\begin{array}{l}\text { Negligible } \\
\text { corrosion }\end{array}$ \\
\hline
\end{tabular}

(a) Measured at the bottom of the cathode.

\section{OPERATION OF THE DISSOLVER}

As shown in Figure 1 , the electrodes are suspended in a stainless steel tank. Up to 5000 amperes at 25 volts DC 1 s supplied from a transformer-rectifier which contains 36 silicon disc rectifiers in parallel; the current is measured with a transducer and controlled with a saturable reactor system. The current is fed to the electrodes through copper buses encased in stainless steel. The electrode flanges are insulated from each other and from the vessel with gaskets of G-7 plastic laminate.

The fuel assemblies are charged to the insulated columblum basket, which is 5 inches by 14 inches by 2.5 feet deep; three a.ssemblies from the Dresden reactor, for example, can be charged at one time. The bottom of the assemblies are submerged in about 2 feet of acid $\left(6-8 \mathrm{M} \mathrm{HNO}_{3}\right)$ and the top extends well up into the charging chute. The current is turned on and the 
voltage is adjusted to 20-25 volts. At this voltage, approximately $2500 \mathrm{amp} / \mathrm{ft}^{2}$ can be passed through platinum. Since the assemblies provide a path of low resistance to the current, 85 to $90 \%$ of the current passes through them, causing them to dissolve at the sloped side facting the cathode.

The assemblies move down as they dissolve, so that more assemblies can be charged on top when there is space. Heat is removed by the coils in the dissolver vessel, with the circulation of liquid alded by an alr sparge under the electrodes and in the bulk solution in the tank. The reaction gases, diluted with air from the spargers, are discharged through a condenser to a stack. The dissolver is normally operated at $60-70^{\circ} \mathrm{C}$. The size of the charge and the volume and concentration of acid are adjusted to ensure that ( $I$ ) the final acid concentration will not be less than $4 \mathrm{M} \mathrm{HNO}_{3}$ (to minimize Pt corrosion), (2) the desired uranium concentration (or plutonium concentration for irradiated fuels) is obtained, and (3) the solubility limit for stainless steel $(\sim 50 \mathrm{~g} / \mathrm{l})$ is not exceeded.

The sludge that is formed during the dissolution of stalnless steel and during the disintegration of zirconium is rinsed with dilute acid to remove any absorbed uranium. After the dissolver solution and rinses have been transferred to the next tank, the sludge is removed from the dissolver by a water spray system located in the bottom of the tank that sweeps the sludge over to the suction leg of the steam jet.

\section{TYPICAL OPERATING RESULTS}

\section{Stainless-Steel-Clad Fuels}

The dissolver was operated inltially with a charge of stainless steel. A mock assembly, 4 in. $x 10.5$ in. $x 10$ ft and weighing 427 pounds (Figure $9 a$ ), was made of $1 / 4-1$ nch type 304L stainless steel pipe arranged in a 6- by 17-plpe array. The assembly is shown in Figure 90 after 64 hours of dissolving at 2500 amperes and 17 to 20 volts. As expected, more than half the stainless steel had been dissolved, and the bottom of the assembly had taken the shape of the sloped section of the cathode. Dissolution was uniform at the bottom, and there was no evidence of arcing between the assembly and basket. A current density of about $3500 \mathrm{amp} / \mathrm{ft}^{2}$ of anode area $\left(0.7 \mathrm{ft}^{2}\right.$ immersed) was maintained throughout the run. After a second stainless steel charge, consisting of two half-width assemblies, was placed on top of the first charge, the run was continued at $3500 \mathrm{amp} / \mathrm{ft}^{2}$. When the run was stopped, less than 0.5 wt $\%$ of the first charge remained, and the second 


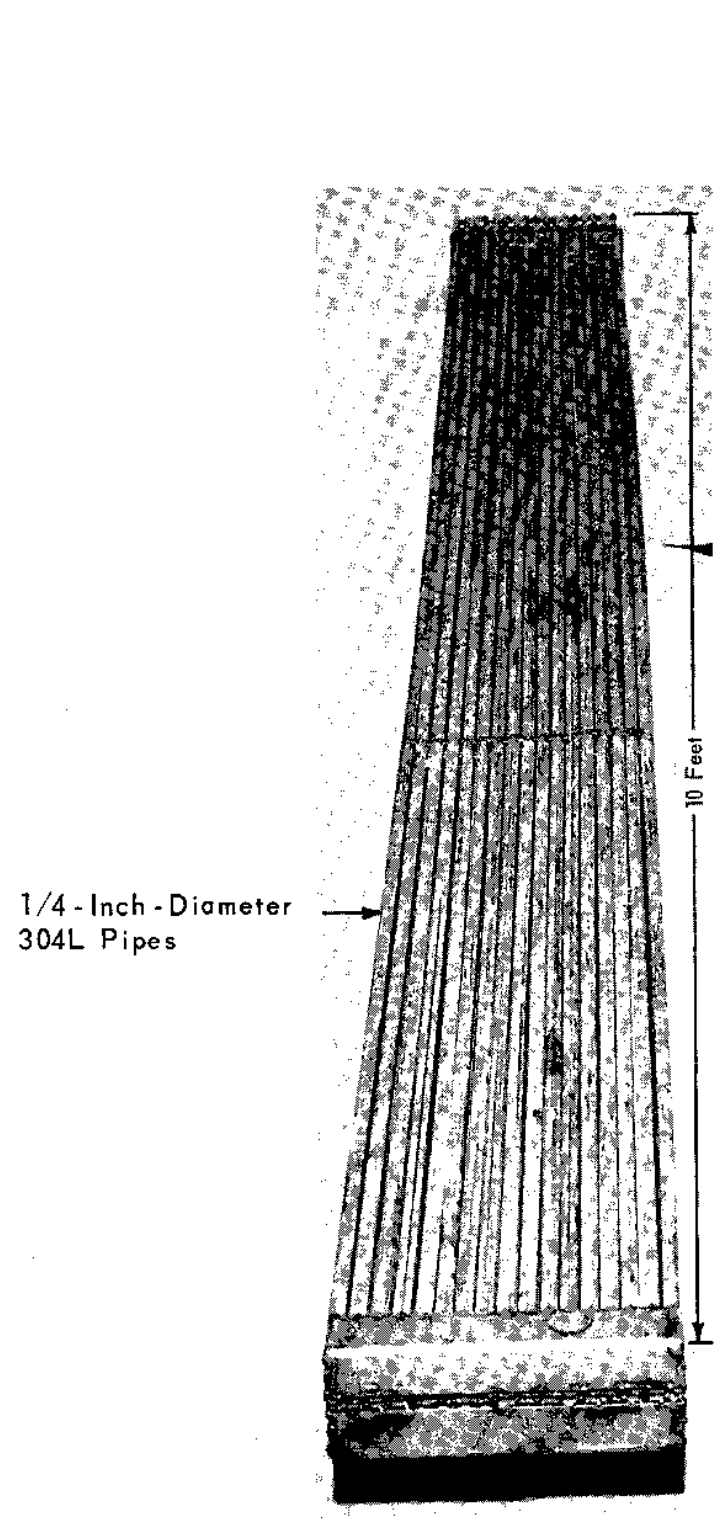

a. As charged
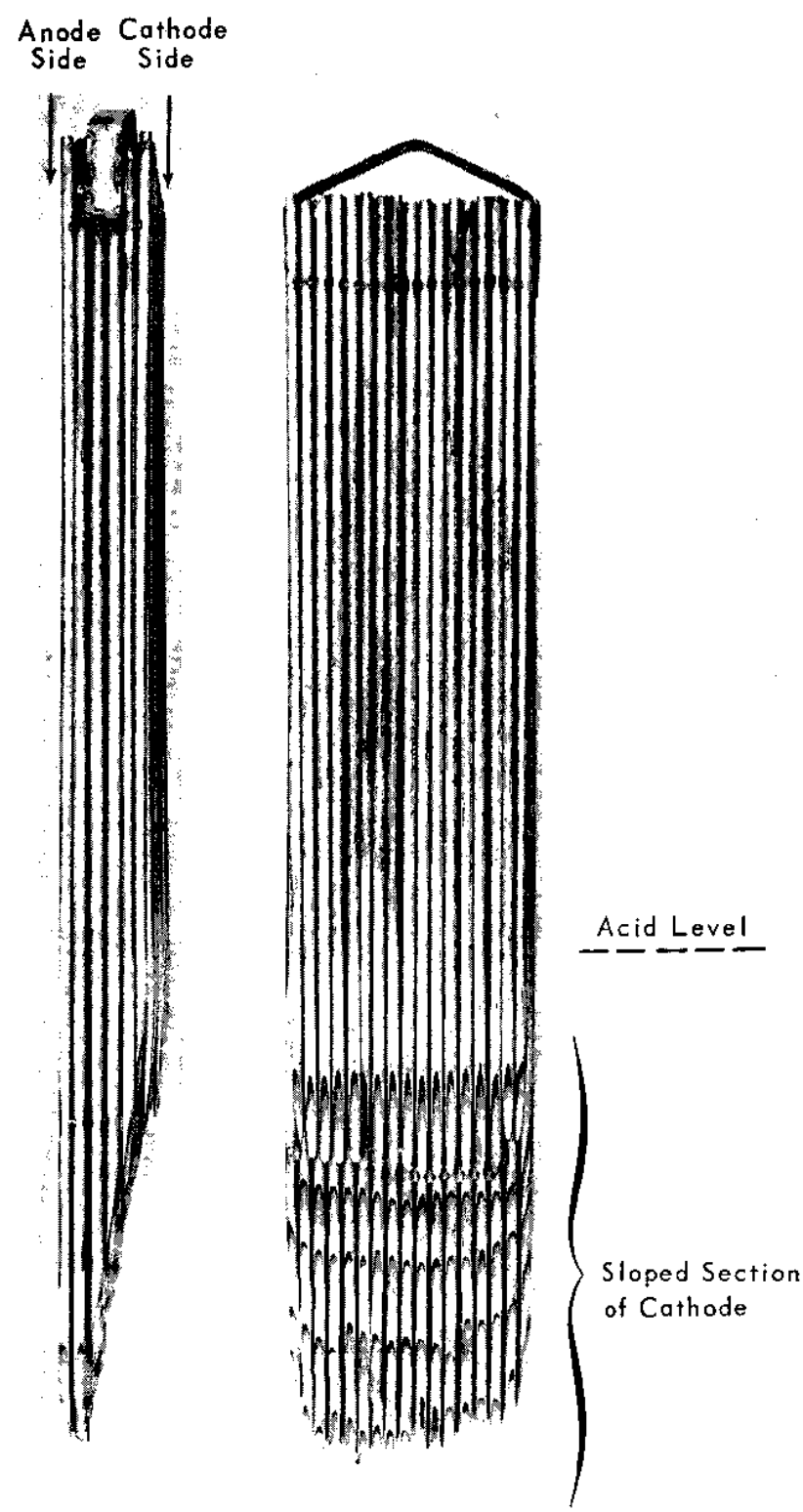

b. Partially dis solved

FIG, 9 MOCK ASSEMBLY OF STAINLESS STEEL FUEL ELEMENTS 

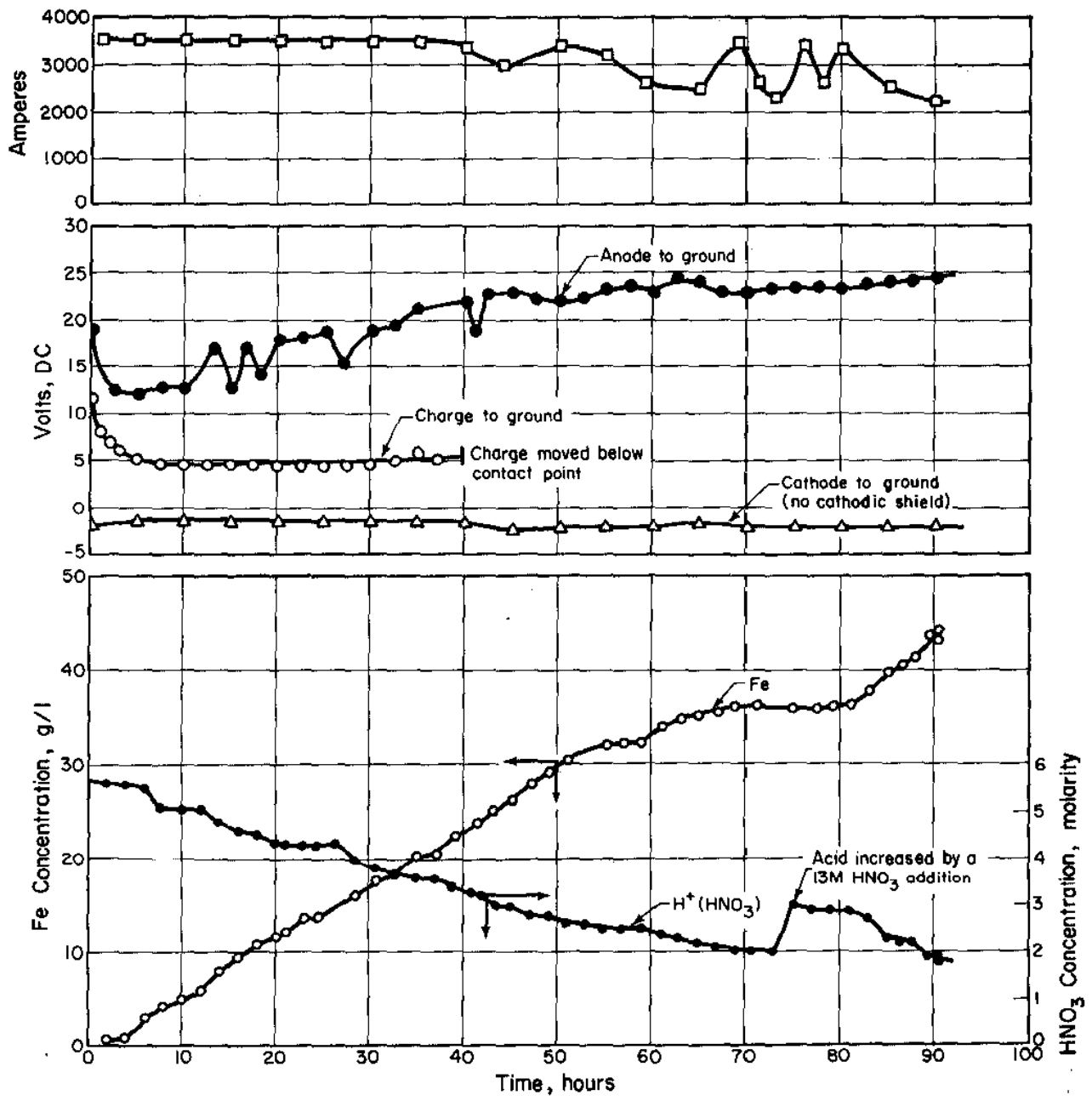

FIG. 10 OPERATING CHARACTERISTICS - STAINLESS STEEL CHARGE

FIG. 11 ZIRCALOY - 4 MOCK POWER FUEL ASSEMBLY 


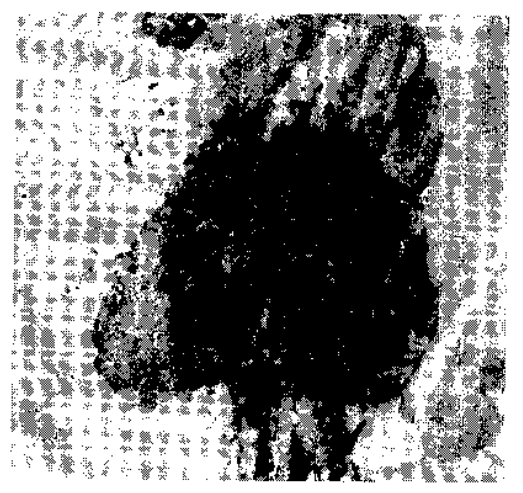

Sample of $\mathrm{ZrO}_{2}$ Sludge Produced

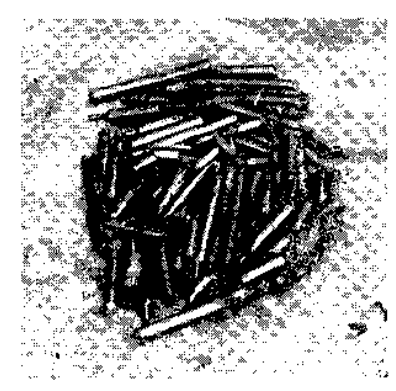

Remoining Cladding

FIG. 12 ZIRCALOY - 4 MOCK POWER FUEL - HEEL
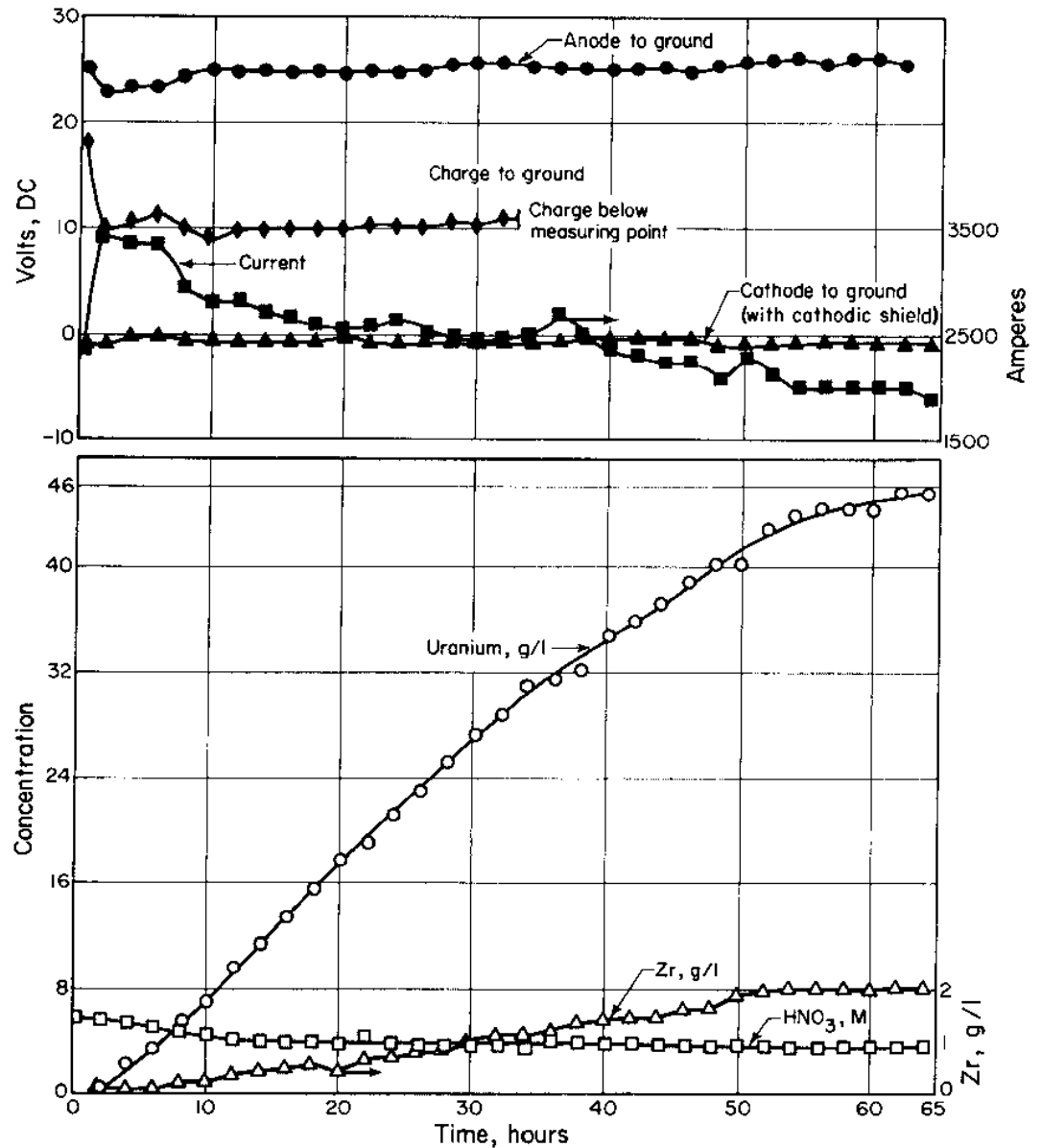

FIG. 13 OPERATING CHARACTERISTICS - ZIRCALOY-CLAD-UO 2 FUELS 
in which Zircaloy was in contact with the anode, $0.85 \mathrm{~g}$ of Zircaloy was disintegrated per amp-hr, regardless of increases in contact resistance (which simply required higher voltage to maintain the same current). With the liquid contact technique, there are two parallel paths for the current, one through the fuel element and one through the nitric acid around the element. If the surface resistance of the zircaloy increases because of a thicker layer of oxide or because of the poorly conducting film produced by autoclaving, then a greater fraction of the current will pass through the acid than $1 f$ the surface resistance is low. Because the current utilization for the zircaloy was 25 to $35 \%$ of theoretical, in contrast to $90 \%$ for the stainless steel, the resistance of the path through the Zircaloy charge must have been 15 to 25 times higher than through the stalnless steel charge.

As expected, $85 \%$ of the Z1rcaloy was converted to an oxide which fell to the bottom of the tank. About 12 gallons of sludge was produced with an estimated bulk density of $0.9 \mathrm{~g} / \mathrm{cm}^{3}$. The successful design of an electrolytic dissolver to process Zircaloy-clad elements required development of a method to remove this siudge from the dissolver vessel. Two methods of sludge removal were investigated and found satisfactory. In the first method, a trough was installed below the electrodes to catch the sludge. The sludge and dissolver solution were continuously pumped from the trough to a decanter or a 200 mesh screen canister where the sludge settled and the solution returned by gravity to the dissolver. In the second method the sludge was allowed to collect in the dissolver and at the completion of the run it was rinsed with dilute acid to remove any absorbed uranium. The sludge was then flushed toward the jet suction by water sprays in the bottom of the tank and removed as a slurry. The second method is preferred because it is less complicated than the first and allows flushing of any absorbed uranium from the sludge prior to removal. The uranium lost to the sludge after three rinses with water was less than 0.5 wt \% of the uranium charged with the fuel as semblies.

\section{$\mathrm{UO}_{2} \cdot$ Stainless Steel Cermet Fuels}

Cermet assemblies of the type used in the Army Package Power Reactors (APPR) were successfully dissolved. A 94-pound charge consisted of Six APPR-type fuel assemblies with an over-all content of 6 wt \% depleted U. Each assembly was a 3 - by 3 - by 27 -inch housing of 1/16-inch stainless steel containing 16 fuel plates clad with stainless steel (Figure 14a). The plates were $35 \mathrm{mils}$ thick and contained a 25-mil core consisting of a dispersion of about 20 wt $\% \mathrm{UO}_{2}$ in stainless 


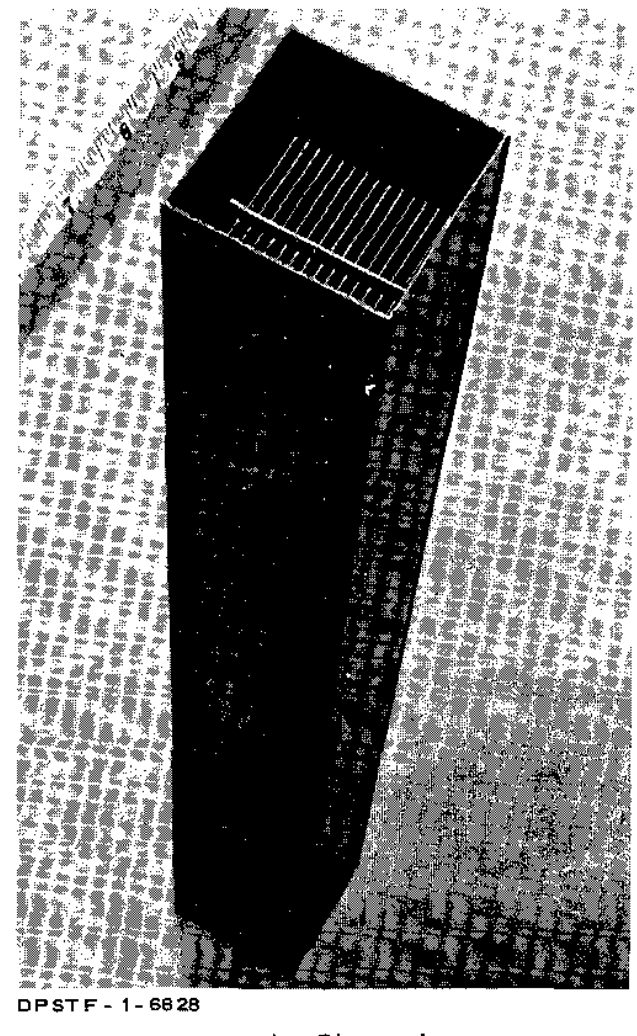

a. As Charged

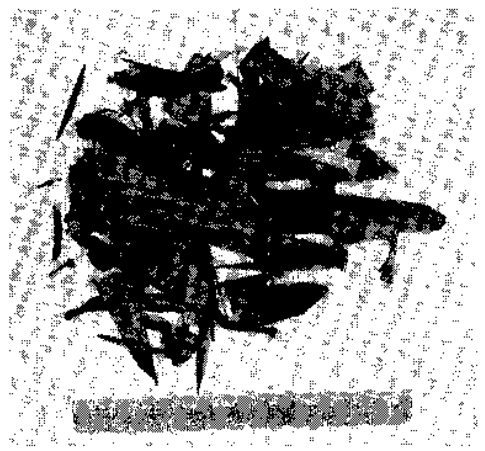

b. Scraps Remaining after Run Completed

FIG. 14 STAINLESS STEEL CERMET ASSEMBLY

steel. The assemblies were dissolved without difficulty in $5.5 \mathrm{M} \mathrm{HNO}_{3}$ at $85^{\circ} \mathrm{C}$ to less than $2 \%$ heel (Figure $14 \mathrm{~b}$ ). The average current was 3000 amperes (2000 amp/ $\mathrm{ft}^{2}$ of anode) at an anode potential of 22 to 25 volts. The average dissolving rate was 1.1 pounds of stainless steel per 1000 amp-hr, equal to a current utilization of $80 \%$. A plot of the operating characteristics is given in Figure 15. About 7 wt $\%$ of the charge appeared as a sludge, and 85 wt $\%$ of the sludge was finer than 100 mesh. Nevertheless, the amount of uranium. lost to the sludge was less than 0.5 wt $\%$ of the uranium charged.

\section{Sodium-Bonded Fuels}

Work on a small scale showed that the stainless steel cladding and $U$-Mo cores of sodium-bonded fuel elements can be dissolved electrolytically at a sufficiently low temperature $\left(60^{\circ} \mathrm{C}\right)$ that the sodium remains solid $\left(\mathrm{m} . \mathrm{p} .=97^{\circ} \mathrm{C}\right.$ ) and does not flow out of the annulus. With the sodium thus held rigldly 

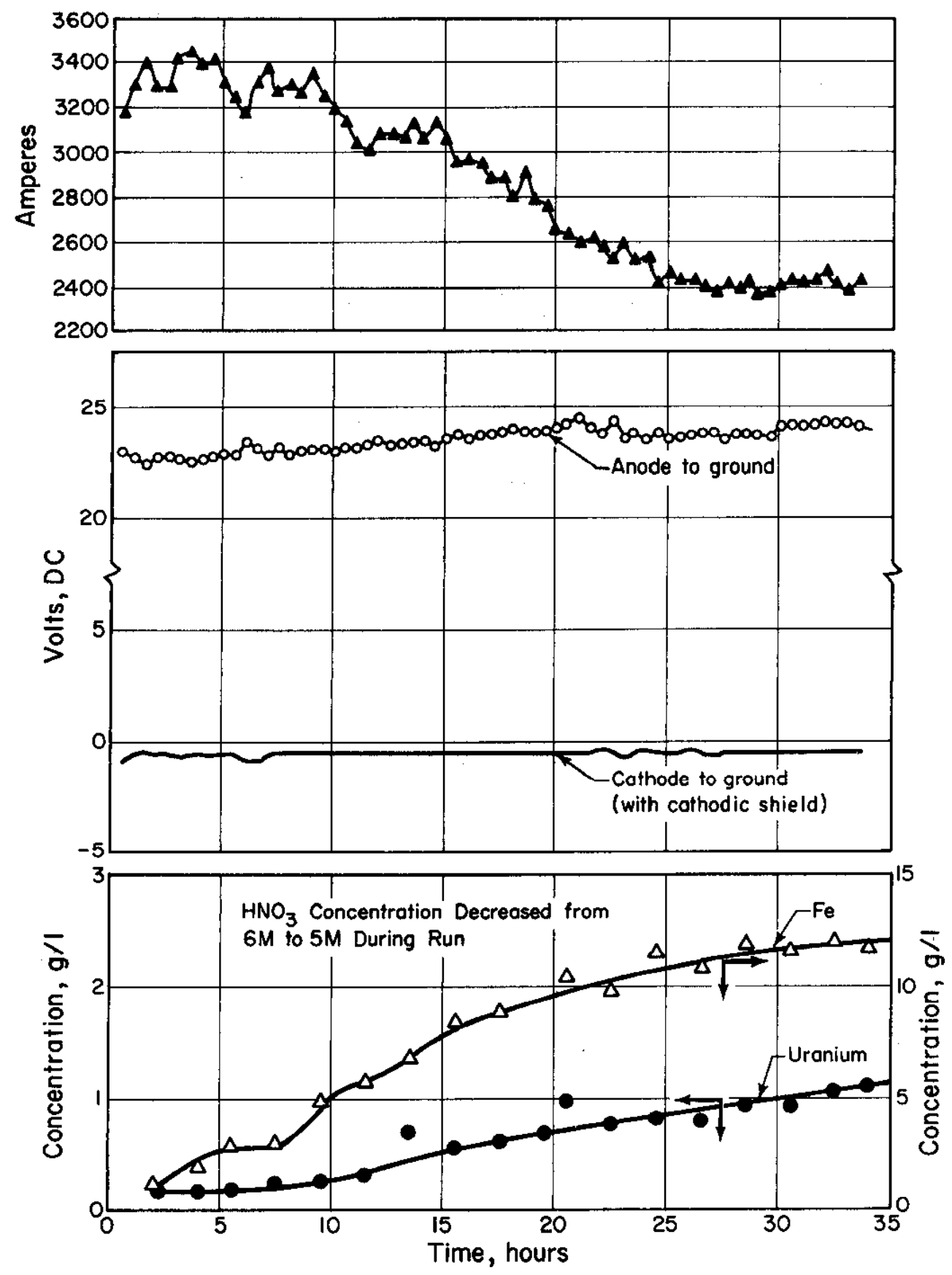

FIG. 15 OPERATING CHARACTERISTICS-STAINLESS STEEL CERMET FUELS 
In place, the rate of exposure of sodium to acia is limited to that allowed by the progressive dissolution of the bottom face of the fuel adjacent to the sloped cathode; the rate of the progressive dissolution is, in turn, controlled by the current.

Clusters of stainless steel tubing, 6 feet long, were assembled to simulate the upper one-third of typical fuel elements from the Hallam reactor (Figure 16). Stainless

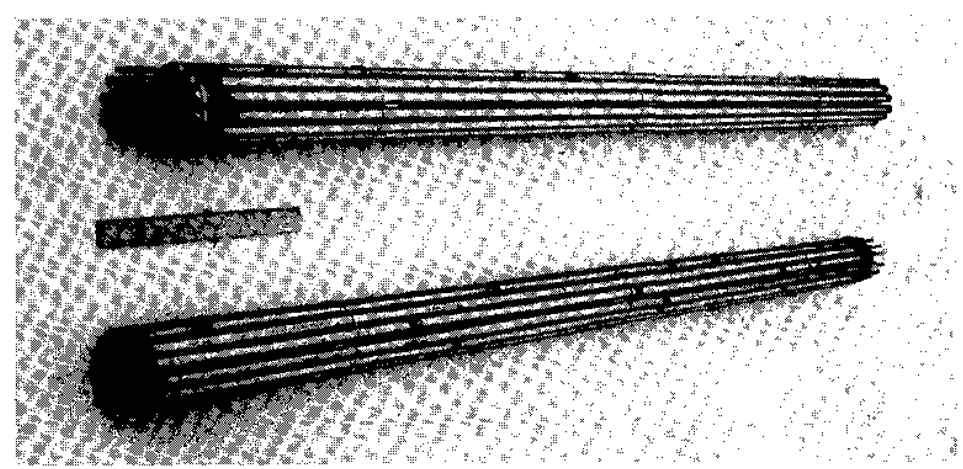

FIG. 16 SIMULATED HALLAM SODIUM-BONDED FUELS

steel pipe was centered within each tube to simulate the uranium-molybdenum core and to form a 25-mil annulus, which was filled with sodium. Three clusters of 18 tubes each were dissolved; the bottom 5 fcot of each cluster contained 900 grams of sodium $(2.7 \mathrm{~kg}$ total sodium) in the annuli. The l-foot section above the "core" contained 3 inches of sodium, and was pressurized with nitrogen at 500 psig to simulate the pressure of gaseous fission products in an irradiated rod. The test assemblies were supported vertically in the columbium basket and were immersed at startup in about 6 inches of $5.5 \mathrm{M}$ $\mathrm{HNO}_{3}$. The depth of immersion increased to about 20 inches as the charge dissolved and moved down along the sloped cathode. As before, the nitric acid in the dissolver was clrculated by an air sparge and was cooled by water in the dissolver coils. Another air sparge, of $4 \mathrm{scfm}$, was directed upward from beneath the electrode to recirculate the electrolyte and remove heat from the basket. A 10-scfm air purge was maintained at the top of the charging chute to prevent the accumulation of hydrogen. The total off-gas rate, including aix leakage into the dissolver, was $70 \mathrm{scfm}$. The temperature of the electrolyte near the fuel assembly was easily controlled at $60^{\circ} \mathrm{C}$, the maximum temperature shown to be safe in earlier tests. The current averaged 3400 amperes, equivalent to $2700 \mathrm{amp} / \mathrm{ft}^{2}$ of platinum anode. The dissolution was smooth with an occasional "popping" sound that was attributed to reacting sodium. Al1 of the sodium had reacted after 40 hours, and <1 wt $\%$ of the 
stainless steel remained undissolved. Analyses of the electrolyte during the dissolution (Figure 17) showed that sodium was released at an average rate of $1.1 \mathrm{~g} / \mathrm{min}$, with a sustained rate of $1.2 \mathrm{~g} / \mathrm{min}$ during a 28 -hour period.

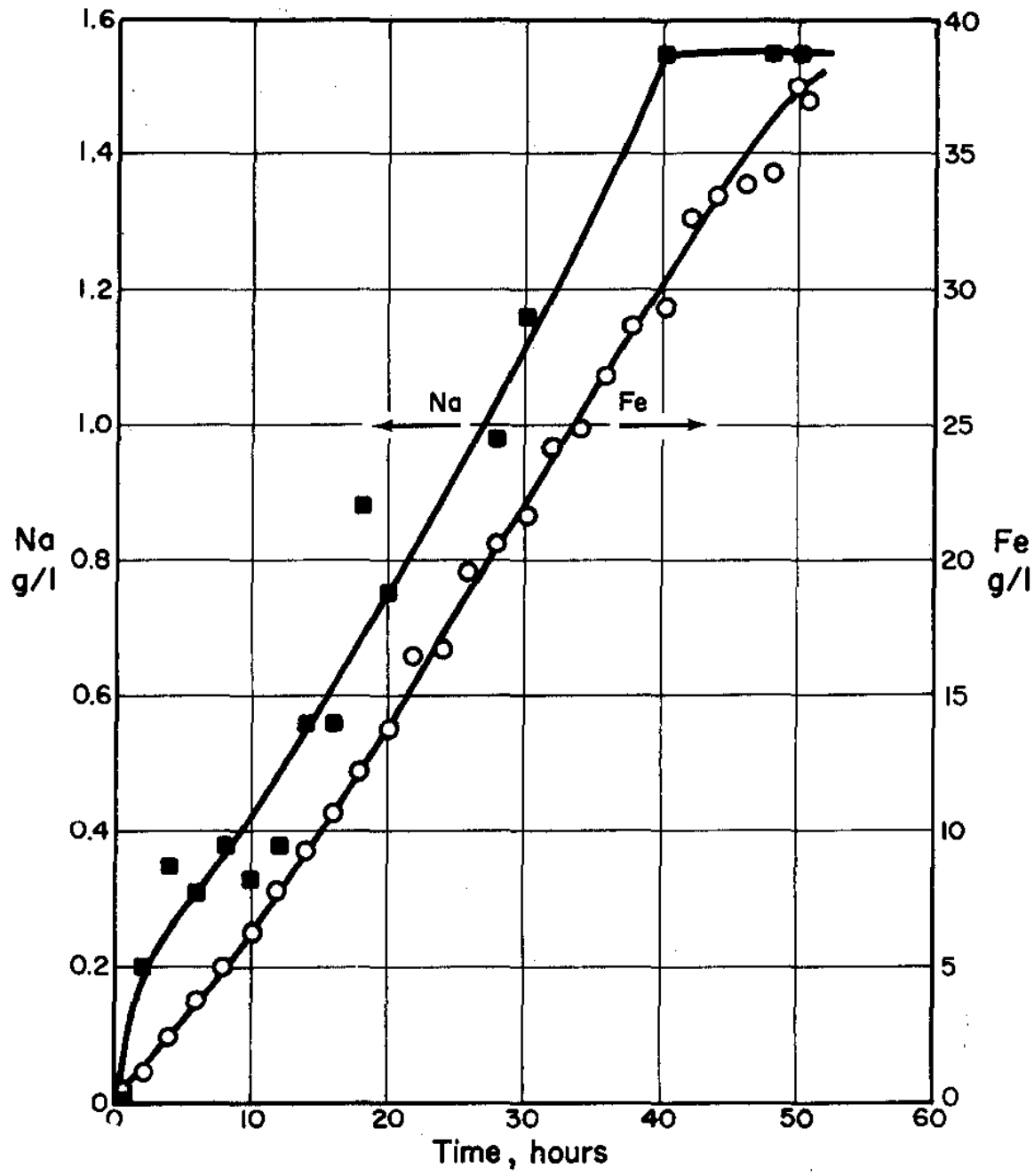

FIG. 17 SOLUTION COMPOSITION - SIMULATED HALLAM SODIUM-BONDED FUELS

Tests were also made in the dissolver with simulated Fermi blanket assemblies and with an unirradiated partial assembly from the Hallam reactor. In both cases the rate of release of sodium was low $(0.1-0.4 \mathrm{~g} / \mathrm{min})$.

The electrolytic technique is not applicable to fuels containing $\mathrm{NaK}$ because the NaK melts at less than $10^{\circ} \mathrm{C}$ and so would quickly flow from the fuel rods once the cladding was breached. 


\section{Aluminum Fuels}

A cluster of 2-inch-diameter aluminum plpes was dissolved in nitric acid at $60-70^{\circ} \mathrm{C}$ at the expected rate of $0.30 \mathrm{~g}$ Al/amp-hr. Although aluminum is readily dissolved in $\mathrm{HNO}_{3}-\mathrm{Hg}$, the electrolytic process may be attractive in some applications because $\mathrm{Hg}$ catalyst is not needed and, unlike the Hg-catalyzed process, the electrolytic process is not slowed by the effects of irradiation on fuel or by the increasing concentration of aluminum in the dissolver solution.

\section{Estimation of Dissolver Capacity}

The capacity of a dissolver of a given size can be estimated from the following information.

- 2000-3000 amp/ $\mathrm{ft}^{2}$ of submerged platinum anode can be passed at $60-80^{\circ} \mathrm{C}$ bulk temperature

- The dissolving rates of various metals are (assuming the basket is filled):

$$
\begin{aligned}
& 0.5 \mathrm{~g} \text { stainless steel/amp-hr } \\
& 0.25 \mathrm{~g} \text { zirconlum/amp-hr } \\
& 2.5 \mathrm{~g} \text { uranium/amp-hr } \\
& 0.3 \mathrm{~g} \text { aluminum/amp-hr }
\end{aligned}
$$

- $\mathrm{UO}_{2}$ dissolves in the $\mathrm{HNO}_{3}$ electrolyte as rapidy as It is exposed by disappearance of the cladding.

- Sodium-bonded fuels can be processed at a sodium exposure rate equivalent to $2.5 \mathrm{~g}$ sodium per minute per square foot of electrode cavity cross section.

The dissolver capacity is limited by the ability to remove heat from the $I^{2} R$ loss; the rates given above assume that the clearance between the fuel assemblies and the electrodes are such that the stated current densities are attained at a potent1al of about 25 volts, or that the electrolyte can be circulated rapidly enough to remove additional heat if higher potentials are required. 


\section{BIBLIOGRAPHY}

1. Pitzer, E. C. Electrolytic Dissolution of Stainless Steel Clad Fuel Assemblies. General Electric Co., Knolls Atomic Power Laboratory, Schenectady, N. Y. USAEC Report KAPL-653 (1951) (Confidential).

2. Martin, F. S. and M. J. Waterman. Head-End Processes for Dissolving Stainless Steel $-\mathrm{UO}_{2}$ Dispersion Type Fuel Elements. United Kingdom Atomic Energy Authority. Research Group. Atomic Energy Research Establishment, Harwel1, Berks, England. USAEC Report AERE-C/R-2454 (1958).

3. Henry, H. E. Electrolytic Dissolution of Stainless Steel. E. I. du Pont de Nemours \& Co., Savannah River Laboratory, Aiken, S. C. USAEC Report DP-396 (1959).

4. Clark, A. T., et al. Electrolytic Dissolution of Power Fuels in Nitric Acid. E. I. du Pont de Nemours \& Co., Savannah River Laboratory, Aiken, S. C. USAEC Report DP-647 (196I).

5. Slansky, C. M., et a.l. Review of Research and Development at the Idaho Chemical Processing Plant on the Electrolytic Dissolution of Nuclear Fuel. Phillips Petroleum Co., Atomic Energy Division, Idaho Falls, Idaho. USAEC Report IDO-14535 (I961).

6. Slansky, C. M., et al., "Electrolytic Dissolution of Reactor Fuels," Nucl. Sci. \& Eng. 12, 33-38 (1962).

7. Proceedings of Symposium, International Symposium of Unit Processes in Hydrometallurgy, "Electrodissolution of Nuclear Fuels", Dallas, Texas, February 24-28, 1963 (To be published).

8. Owen, J. H., Comp. Reprocessing of Power Reactor Fuels Fourteenth Quarterly Progress Report - January I to April I, 1961. E. I. du Pont de Nemours \& Co., Savannah R1ver Laboratory, Aiken, S. C. USAEC Report DP-588 (1961).

9. Owen, J. H., Comp. Processing of Power Reactor Fuels Fifteenth Quarterly Progress Report - April 1 to July 1 , 1961. E. I. du Pont de Nemours \& Co., Savannah River Laboratory, Aiken, S. C. USAEC Report DP-626 (1961).

10. Rust, F. G., Comp. Processing of Power Reactor Fuels S1xteenth Quarterly Progress Report - July I to October I, 1961. E. I. du Pont de Nemours \& Co., Savannah River Laboratory, Aiken, S. C. USAEC Report DP-706 (1962). 
11. Caracciolo, V. P., Comp. Processing of Power Reactor Fuels - Seventeenth Quarterly Progress Report - October 1, 1961 to January 1, 1962. E. I. du Pont de Nemours \& Co., Savannah River Laboratory, Aiken, S. C. USAEC Report DP-720 (1962).

12. Clark, A. T., Jr., Comp. Processing of Power Reactor Fuels - Elghteenth Quarterly Progress Report - January I to April 1, 1962. E. I. du Pont de Nemours \& Co., Savannah River Laboratory, Aiken, S. C. USAEC Report DP-740 (1962).

13. Owen, J. H., Comp. Processing of Power Reactor Fuels Nineteenth Quarterly Progress Report - April I to July 1 , 1962. E. I. du Pont de Nemours \& Co., Savannah R1ver Laboratory, Aiken, S. C. USAEC Report DP-782 (1962).

14. Owen, J. H., Comp. Processing of Power Reactor Fuels Twentieth Quarterly Progress Report - July 1 to October 1, 1962. E. I. du Pont de Nemours \& Co., Savannah River Laboratory, Aiken, S. C. USAEC Report DP-811 (1962).

15. Caracciolo, V. P., Comp. Processing of Power Reactor Fuels - Twenty-first Quarterly Progress Report October I, 1962 to January 1, 1963. E. I. du Pont de Nemours \& Co., Savannah River Laboratory, A1ken, S. C. USAEC Report DP-824 (1963).

16. Kishbaugh, A. A., Comp. Processing of Power Reactor FueIs - Twenty-Second Quarterly Progress Report January 1 to April 1, 1963. E. I. du Pont de Nemours \& Co., Savannah River Laboratory, Aiken, S. C. USAEC Report DP-839 (1963).

17. Mirsch, C. M. and W. E. Ruther, "The Anodizing of Zirconium and Other Transition Metals in Nitric Acid," J. Electrochem. Soc. 100, No. 12, 531-37. (1953).

18. Glasstone, S. and A. Hickling. Electrolytic Oxidation and Reduction: Inorganic and Organic. D. Van Nostrand Co., Inc. (1936) p 224. 